\title{
Prediction of financial condition of Indonesian banks using Altman Z- Score model
}

\author{
St Ibrah Mustafa Kamal ${ }^{1}$, Luksi Visita ${ }^{2}$ \\ ${ }^{1}$ Faculty of Economics, UIN Alauddin Makassar, Indonesia \\ ${ }^{2}$ Faculty of Islamic Economics and Business, UIN Walisongo Semarang, Indonesia
}

\begin{abstract}
Purpose - Banking is one of the hearts of the economy in Indonesia. This study aims to determine the financial condition of banking in Indonesia.

Method - The data in this study used financial reports of bank. The technique of data analysis used the Altman Z-Score model by using five variables that represent the liquidity ratio $X 1, X 2$ and $X 3$ profitability, $X 4$ and $X 5$ activities. With the criteria of assessment Z-Score $>2.99$, it is categorized as a very healthy company. $1.81<Z$ Score $<2.99$ is in the gray area so that the probability of being saved and the possibility of bankruptcy are the same depending on the policy decision of the company management as the decision maker. Z-Score $<1.81$ is categorized as a company which has an enormous financial problem at high risk, so that the possibility of bankruptcy is very large.
\end{abstract}

Result - As the result, it can be seen that Indonesian banks from 2008-2010 were at risk of going through financial difficulties and then survived, and in the following years became more stable; while some banks were unstable but survived and fixed their financial issues.

Implication - This research can help Indonesian banks to evaluate their financial performance.

Originality - The originality of this research lies in the object under study, test analysis, and research location.

Keywords: financial performance, Indonesian banks 


\section{Introduction}

The Indonesian economy will increasingly develop in accordance with the various kinds of financial institutions that support it. One of the financial institutions is a bank. The activities

JIEMB | 68 carried out by the Indonesian people in general cannot be separated from the stability of the bank. In addition to saving money, banks have also become focused on financing, credit and payment systems activities in the economic sector. The economic crisis that has occurred in Indonesia has given an impact on the banking industry which has experienced a crisis and even bankruptcy. This is the reason why many researchers try to find the cause.

Researchers then focused a lot on the high risk of companies occurring due to the uncertainty of the Indonesian economy so that the likelihood of experiencing financial difficulties or even bankruptcy was higher. Therefore, prediction of a company's financial condition is very important (Atmini, 2005). Likewise, investors and creditors who wish to invest will first assess the company's financial condition (Hadi \& Anggraeni, 2010).

Researchers and investors rarely predict bank financial conditions by using the Altman Z-Score model, especially for banks. On the other hand, if there is a prediction error, it will affect the continuity of a company's operations in the next period and have fatal consequences such as loss of existing income or investment. The importance of predicting the bankruptcy of a company, especially banks, needs to be considered for various parties such as customers, investors, borrowers, managers and accountants to be able to find out bankruptcy predictions assessed from several indicators based on bank financial reports. Prediction results can help interpret various relationships and trends that can provide a basis for consideration of the future of a bank to survive or not (Munawir, 2002).

\section{Literature review}

The limitations of ratio analysis arise from the fact that the methodology is essentially univariate, which means that each ratio is tested separately. To overcome the weaknesses of these analyses, Altman has combined several ratios into a predictive model with statistical analysis techniques, namely discriminant 
analysis which produces an index that allows the classification of an observation into one of several a priori groupings (Weston \& Copeland, 2004: 254 in Iflaha, 2008).

One of the studies regarding the Z-Score was conducted by Professor Edward L. Altman. In 1968 he predicted bankruptcy using the MDA (Z-Score method) and was able to predict the company up to $95 \%$ accuracy for 12 months. Another test was carried out by Altman by taking several samples of companies with different economic climates and the accuracy rate of the test was $82 \%$ to $85 \%$. The Altman Z-Score model which has been used with various statistical tests produces a bankruptcy prediction model that can be used according to the type of company.

The Altman score for banking companies that have gone public is determined using the following formula (Munawir, 2002: 309):

$$
\text { Z-Score }=1.2 X_{1}+1.4 X_{2}+3.3 X_{3}+0.6 X_{4}+1.0 X_{5} \text {. }
$$

With:

$$
\begin{aligned}
& \mathrm{X}_{1}=\begin{array}{l}
\text { Working capital to total assets (working capital/total } \\
\text { assets) }
\end{array} \\
& \mathrm{X}_{2}=\begin{array}{l}
\text { Retained earning to total assets (retained } \\
\text { earnings/total assets) }
\end{array} \\
& \mathrm{X}_{3}=\begin{array}{l}
\text { Earning before interest and taxes (EBIT) to total } \\
\text { assets (income before deducting interest costs/total } \\
\text { assets) }
\end{array} \\
& \mathrm{X}_{4}=\begin{array}{l}
\text { Market value of equity to book value of total liabilities } \\
\text { (stock market price in stock market/total value of }
\end{array} \\
& \mathrm{X}_{5}=\begin{array}{l}
\text { debt) } \\
\text { Sales to total assets (sales/total assets) }
\end{array}
\end{aligned}
$$

These five ratios were used to analyze a company's financial statements for then detect the possibility of bankruptcy in the company. In financial management, the ratios used in the Altman model can be categorized into three major groups, namely the liquidity ratio consisting of $X 1$, the profitability ratio consisting of $X 2$ and $X 3$, the activity ratio consisting of $X 4$ and $X 5$. The description of each of these variables are as follows:

a) Working capital to total assets is used to measure the liquidity of the company's assets relative to total capitalization, or to measure the company's ability to meet short-term obligations. Indicators that can be used to detect problems with the 
company's liquidity level are internal indicators such as insufficient cash, trade payables, and several other indicators.

b) Retained earnings to total assets are used to measure the cumulative profitability. This ratio measures the accumulated profit during the company's operation. The company's age has an effect on this ratio because the longer the company operates, it allows it to smoothen the accumulation of retained earnings. This can cause companies that are relatively young in general to show low yield ratios, except for those with very large profits in their early days.

c) Earning before interest and taxes to total assets is used to measure the actual productivity of the company's assets. The ratio measures the company's ability to generate profits from the assets used. This ratio is the biggest contributor to the model. Some of the indicators that we can use to detect problems with the company's profitability include increased accounts receivable, continuous losses in several quarters, increased inventory, decreased sales, and late collection of accounts receivable.

d) The market value equity to book value of total debt is used to measure how much the company's assets can decline in value before the amount of debt is greater than its assets and the company becomes bankrupt. Capital in question is the combined market value of ordinary capital and preferred stock, while debt includes current debt and long-term debt.

e) Sales to total assets are used to measure management's ability to face competitive conditions. The ratio measures management's ability to use assets to generate sales.

Discriminant analysis is carried out to predict the bankruptcy of a company by analyzing the company's financial statements in two to five years before the company is predicted to go bankrupt (Endri, 2009). Bankruptcy is a condition when a company experiences insufficient funds to run its business. Bankruptcy is usually associated with financial difficulties. Discriminant analysis is useful for companies to obtain early warnings of bankruptcy and to continue their business.

In 2005, BAPEPAM (Badan Pengawas Pasar Modal/Capital Market Supervisory Agency) for a capital market efficiency improvement project made a study on electronic financial statement 
analysis and included the Altman Z-Score as an example of an analysis system. However, using the Altman Z-Score model has both advantages and disadvantages. According to BAPEPAM (2005), the advantages of the Z-Score results include:

a) Combining various financial risks together.

b) Providing appropriate coefficients to combine independent variables.

c) Easy to apply.

While the weaknesses of the Z-Score results include:

a) The Z-Score value can be manipulated or biased through wrong accounting principles or other financial engineering.

b) The formula is Z-Score not appropriate for new companies whose profits are still low or even still losing money. The ZScore will usually be low.

c) Z-Score calculation on a quarterly basis in a company can give inconsistent results if the company has a policy to write off accounts receivable at the end of the year at once.

Purwanti (2005) examined the financial ratios in the Altman ZScore model and found that there is no financial ratio model that can be used to predict the company's financial condition other than the combined ratios of the Altman Z-Score model. In addition, in the same year, Nugraheni took a sample of 17 banking companies in 1999-2003 for her research on the Analysis of the Accuracy of Potential Bankruptcy Prediction through the Altman Z-Score and Its Relationship with Stock Prices in Banking Companies Listing on the Jakarta Stock Exchange. The documentation was taken from banking financial reports and supporting books. Analysis of the data used in this study is the Altman analysis Z-Score and Correlation of Pearson Product Moment. The results showed that for five consecutive years, the Z-Score values of all banking companies were still below 1.2 so that it was in the third area, which was predicted to be bankrupt. The results of other studies indicate that the potential bankruptcy of the Altman Z-Score is related to stock prices with a correlation of $22.6 \%$ with a trust level of $95 \%$. The conclusion from this research is that the Altman Z-Score can be applied to predict the potential for bankruptcy in Indonesia.

In 2008, several researchers also used Altman Z-Score as a tool in predicting the company's financial condition. Rudyawan and 
Badera (2008) stated that the assessment of going concern must be submitted by the auditor and added to the audit opinion. The auditor is responsible for evaluating whether there is substantial doubt about the entity's ability to continue operating for a reasonable period of time. This study aimed to determine the effect of the Altman bankruptcy prediction model, company growth, leverage, and auditor reputation on concerns over audit opinion. The results showed that the bankruptcy prediction by using Altman model affected the accuracy of the problem of going-concern opinion. However, company growth, leverage, and auditors' reputation did not.

\section{Methodology}

This study used secondary data derived from IDX's website (www.idx.co.id). The data used were the financial statements of banking which went public in 2008-2010. In addition, the data were processed to obtain the value of each variable and then calculated using the formula from the Altman Z-Score. In addition, literature studies were done using various reference sources for books, research articles, research results, and mass media. The research sample used 20 banks which were in the top order of banking companies on the Indonesia Stock Exchange 2008-2010. Table 1 is a list of the names of the banks as the research samples.

The analysis used the Altman Z-Score model. Altman found five types of financial ratios that can be combined to see the difference between companies that are bankrupt and those that are not. Altman Z-Score for banking companies that have gone public is

Table 1. List of name of banks

\begin{tabular}{|c|c|c|c|}
\hline No & Name of banks & No & Name of banks \\
\hline 1 & Bank Artha Graha Internasional Tbk. & 11 & Bank Kesawan Tbk. \\
\hline 2 & Bank Bumi Artha Tbk. & 12 & Bank Mandiri (Persero) Tbk. \\
\hline 3 & Bank Bukopin Tbk. & 13 & Bank Mega Tbk. \\
\hline 4 & Bank Capital Indonesia Tbk. & 14 & Bank Negara Indonesia Tbk. \\
\hline 5 & Bank Central Asia Tbk. & 15 & Bank OCBC NISP Tbk. \\
\hline 6 & Bank CIMB Niaga Tbk. & 16 & Bank Pan Indonesia Tbk. \\
\hline 7 & Bank Danamon Indonesia Tbk. & 17 & Bank Permata Tbk. \\
\hline 8 & Bank Ekonomi Raharja Tbk. & 18 & Bank Rakyat Indonesia Tbk. \\
\hline 9 & Bank Brothers Association 1906 Tbk. & 19 & National Pension Savings Bank Tbk. \\
\hline 10 & Bank Internasional Indonesia Tbk. & 20 & Bank Victoria International Tbk. \\
\hline
\end{tabular}


determined using the following formula (Munawir, 2002 and Warastuti \& Sitinjak, 2014).

Z-Score $=1.2 X_{1}+1.4 X_{2}+3.3 X_{3}+0.6 X_{4}+1.0 X_{5}$. With:

$X_{1}=$ Working capital to total assets (working capital/total assets)

$\mathrm{X}_{2}=$ Retained earning to total assets (retained earnings/total assets)

$X_{3}=$ Earning before interest and taxes (EBIT) to total assets (income before deducting interest costs/total assets)

$X_{4}=$ Market value of equity to book value of total liabilities (stock market price in stock market/total value of debt)

$X_{5}=$ Sales to total assets (sales/total assets)

With assessment criteria (Munawir, 2002) as follows:

a) Z-Score $>2.99$ is categorized as a very healthy company so that it does not experience financial difficulties.

b) $1.81<Z$-Score $<2.99$ is in a gray area so that it is categorized as a company that has financial difficulties, but the possibility of being saved and the possibility of bankruptcy are the same depending on the decision of the company's management policy as the decision maker.

c) Z-Score $<1.81$ is categorized as a company that has enormous financial difficulties and has a high risk of going bankrupt.

\section{Results and discussion}

Z-Score Altman model is used in calculating the prediction of bankruptcy of Indonesian banks. The financial statements of each sample that have been collected then produce the following data. Twenty (20) banks in Indonesia used in the Z-Score Altman model in 2008 were experiencing bankruptcy or the Z-Score Altman prediction was experiencing bad financial conditions.

\section{Altman Z-score calculation results}

Table 2 shows that in the last three years, from 2008 to 2010 , each bank had a different financial condition for each year. There 
Table 2. Prediction of Bankruptcy for Banking Companies in 2008-2010

\begin{tabular}{cllll}
\hline \multirow{2}{*}{ No } & Name of banks & \multicolumn{3}{c}{ Year } \\
\cline { 2 - 5 } & 2008 & 2009 & 2010 \\
\hline 1 & Bank Artha Graha Internasional Tbk. & Bankrupt & Bankrupt & Bankrupt \\
2 & Bank Bukopin Tbk. & Bankrupt & Gray Area & Healthy \\
3 & Bank Bumi Artha Tbk. & Bankrupt & Gray Area & Healthy \\
4 & Bank Capital Indonesia Tbk. & Bankrupt & Healthy & Healthy \\
5 & Bank Central Asia Tbk. & Bankrupt & Healthy & Healthy \\
6 & Bank CIMB Niaga Tbk. & Bankrupt & Bankrupt & Healthy \\
7 & Bank Danamon Indonesia Tbk. & Bankrupt & Healthy & Bankrupt \\
8 & Bank Ekonomi Raharja Tbk. & Bankrupt & Healthy & Bankrupt \\
9 & Bank Himpunan Saudara 1906 Tbk. & Bankrupt & Healthy & Healthy \\
10 & Bank Internasional Indonesia Tbk. & Bankrupt & Bankrupt & Gray Area \\
11 & Bank Kesawan Tbk. & Bankrupt & Bankrupt & Healthy \\
12 & Bank Mandiri (Persero) Tbk. & Bankrupt & Healthy & Healthy \\
13 & Bank Mega Tbk. & Bankrupt & Bankrupt & Bankrupt \\
14 & Bank Negara Indonesia Tbk. & Bankrupt & Healthy & Healthy \\
15 & Bank OCBC NISP Tbk. & Bankrupt & Bankrupt & Bankrupt \\
16 & Bank Pan Indonesia Tbk. & Bankrupt & Bankrupt & Bankrupt \\
17 & Bank Permata Tbk. & Bankrupt & Bankrupt & Bankrupt \\
18 & Bank Rakyat Indonesia Tbk. & Gray Area & Healthy & Healthy \\
19 & National Savings Bank Tbk. & Bankrupt & Bankrupt & Healthy \\
20 & Bank Victoria International Tbk. & Bankrupt & Gray Area & Bankrupt
\end{tabular}

were six banks which in 2008 were in a bankrupt condition and in the last two years had a healthy condition, namely Bank Capital Indonesia Tbk., Bank Central Asia Tbk., Bank Himpunan Saudara 1906 Tbk., Bank Kesawan Tbk., Bank Negara Indonesia Tbk., and Bank Rakyat Indonesia Tbk. However, there were still five banks that in three years were still bankrupt in accordance with the Altman ZScore criteria for publicly listed banking companies, namely Bank Artha Graha International Tbk., Bank Mega Tbk., Bank OCBC NISP Tbk., Bank Pan Indonesia Tbk., and Bank Permata Tbk.

Bank Bukopin Tbk. and Bank Bumi Artha Tbk. experienced a financial condition that were developing slowly. It can be seen that from 2008 it was in a state of bankruptcy according to the Altman ZScore criteria. In 2009, it was in the gray area and in 2010 it was in a healthy condition. Bank CIMB Niaga Tbk. and Bank Tabungan Pensiunan Nasional Tbk. were in a condition of bankruptcy in the first two years, then in 2010 experienced a healthy condition. Bank Danamon Indonesia Tbk., and Bank Ekonomi Raharja Tbk. went bankrupt in 2008, then increased in 2009 with a healthy condition, but in the following year they were again in a bankrupt condition. Bank Internasional Indonesia Tbk. went bankrupt in the first two 
years and in 2010 was in the gray area. Bank Victoria International Tbk. went bankrupt in 2008 then increased in 2009 by being in the gray area and then went bankrupt again in 2010.

In 2008, Bank Rakyat Indonesia, Tbk. was in the gray area. In 2009 , it was found that the same banking company was trying to improve its financial condition, which can be seen from the Altman calculation that the Z-Score already has a condition from bankruptcy to gray area. There are even several companies that went bankrupt in 2008 such as Bank Capital Indonesia, Tbk., Bank Central Asia Tbk., Bank Danamon, Tbk., Bank Ekonomi Raharja, Tbk., Bank Himpunan Saudara 1906 Tbk., and Bank Negara Indonesia Tbk.

In 2010, banking in Indonesia experienced a very good financial condition improvement. Even so, there were Bank Artha Graha Internasional Tbk., Bank OCBC NISP Tbk., Bank Mega Tbk., Bank Permata Tbk., and Bank Pan Tbk. which had experienced financial conditions predicted to go bankrupt three years in a row. According to the Altman Z-Score model, this bank would soon experience bankruptcy due to no improvement in its financial condition.

In contrast to 2008 and 2009, in 2010, the financial condition of Indonesian banks was generally predicted to be healthy. Thus, these banks were predicted to last a long time in the Indonesian banking sector. Even Bank Rakyat Indonesia Tbk. is still in exhibition and has become one of the largest banks with many branches in Indonesia.

Five variables used to calculate the Z-Score value of a banking company are (X1) Working Capital to Total Assets, (X2) Retained Earning to Total Assets, (X3) Earning before Interest and Taxes (EBIT) to Total Assets, (X4) )Market Value of Equity to Book Value of Total Liabilities, and (X5) Sales to Total Assets (Harahap, 2009: 353). Between one and another variables have a relationship that affects each other. The value of working capital is large indicating that the productivity of the company's assets is able to generate large operating profits as expected by banking companies. With the increase in the company's operating profit, it will attract investors to invest in the company so that the company's retained earnings will increase. The increase in retained earnings and working capital owned by the company will encourage an increase in total sales of banking companies. Likewise, if the working capital owned by the 


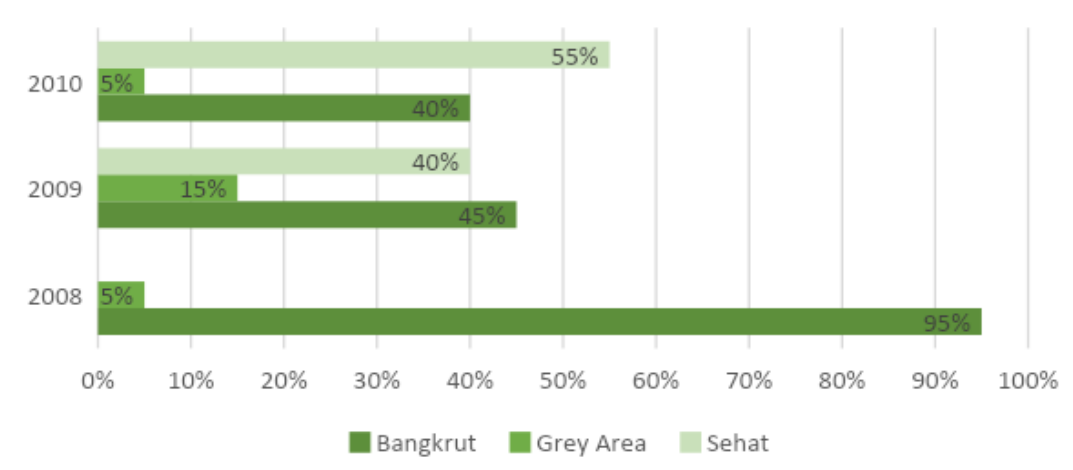

Figure 1. Financial Condition of Indonesian Banking

company is getting smaller, the company will get a small profit, too. If a company experiences something like this, it will lead to financial difficulties, and if this situation continues, the company will go into bankruptcy.

In Figure 1, it can be seen that the prediction of bankruptcy in banking companies is getting better every year. The prediction of bankruptcy experienced by banks from 2008 was $95 \%$, decreased in 2009 to $45 \%$, and decreased again to $40 \%$ in 2008 . The decline in banking companies predicted to go bankrupt was followed by healthy financial conditions in 2009 by $40 \%$ and increasing $15 \%$ to $55 \%$ in 2010 . Whereas in the gray area in 2008 , it was $5 \%$, increased to $15 \%$ in 2009 , and decreased to $5 \%$ in 2010 .

In 2010 , the prediction of bankruptcy in banks has a result $55 \%$ of banks are healthy, $5 \%$ are in the gray area, and $40 \%$ are still predicted to be bankrupt. The chances of this bankruptcy will certainly be even greater if the company management does not immediately take action to evaluate the company's financial condition. In addition, performance improvement is needed by each bank so that it is less likely to experience bankruptcy.

\section{Conclusion}

This research can provide predictions and an overview of the financial condition of banks in Indonesia in 2008 which were still bankrupt but could continue to improve their performance so that in 2010 they were still alive and well. Even today, there are several banks in this study that are in the top position as the largest banks 
in Indonesia, such as Bank Negara Indonesia, Tbk., Bank Rakyat Indonesia and Bank Central Asia, Tbk.

The author hopes that further studies can use other bankruptcy prediction models to be used as a comparison in predicting bankruptcy. The limitation in this study is related to the number of variables used only for quantitative assessments, so that further research can also consider qualitative aspects such as economic, social, technological, and changes in government regulations that lead to the bankruptcy of a company.

The author also hopes that the company pays attention to the variables used with the Altman model. Based on the above conclusions, the management of the company should be more careful in terms of asset management so that the resulting working capital flows are not negative. Investing in receivables that are too large is also dangerous because it can cause the company's performance to be disrupted.

\section{References}

Endri. 2009. Prediksi Kebangkrutan Bank Untuk Menghadapi dan Mengelola Perubahan Lingkungan Bisnis: Analisis Model Altman's ZScore. Perbanas Quarterly Review, 2(1).

Harahap, Sofyan Safri. 2009. Critical Analysis of Financial Statements. Jakarta: PT. Raja Grafindo Persada.

Iflaha, Diana Atim. 2008. Analisis Financial Distress dengan Metode ZScore Untuk Memprediksi Kebangkrutan Perusahaan. (Studi pada Perusahaan Restoran, Hotel dan Pariwisata yang Listing di Bursa Efek Indonesia Periode 2003-2007). Skripsi Fakultas Ekonomi Jurusan Manajemen. Universitas Islam Negri Maulana Malik Ibrahim.

Munawir, S. 2002. Analysis of Financial Information. Yogyakarta: Liberty Yogyakarta

Nugraheni, Aprilia. 2005. Analisis Ketepatan Prediksi Potensi Kebangkrutan Melalui Altman Z-Score dan Hubungannya dengan Harga Saham pada Perusahaan Perbankan yang Listing di Bursa Efek Jakarta, Universitas Negeri Semarang.

Purwanti, Yulia.2005. Analisis Rasio Keuangan dalam Memprediksi Kondisi Keuangan Financial Distress Perusahaan Manufaktur yang Terdaftar di Bursa Efek Jakarta. Skripsi. Fakultas Ekonomi. Universitas Islam Indonesia. Yogyakarta. 
Rudyawan, Arry Pratama and Badera, I Dewa Nyoman. 2009. Opini Audit Going Concern: Kajian Berdasarkan Model Prediksi Kebangkrutan, Pertumbuhan Perusahaan, Leverage, Dan Reputasi Auditor. Archives, VOL.4 No.2, 2009, halamn 1-17. https://ojs.unud.ac.id/index.php/jiab/article/view/2612/1823

Warastuti, Yusni dan Sitinjak, Elizabeth Lucky Maretha, 2014. Analysis Of Model-Based Prediction Of Bank Bankruptcy In The Banking Companies Listed In Indonesia Stock Exchange 2008-2012. South East Asia Journal of Contempory Business, Economics and Law, Vol. 5 , Issue 1 (Dec). page 71-81. 